\title{
A MANYE 30 éves fennállásának jubileumi konferenciája
}

\section{(MANYE, online konferencia, 2020. december 4.)}

\author{
Malaczkov Szilvia \\ E-mail:malaczkov.szilvia@uni-bge.hu
}

\begin{abstract}
A Magyar Alkalmazott Nyelvészek és Nyelvtanárok Egyesületének (MANYE) jogelődje 1990-ben alakult, így idén ünnepeltük fennállásának 30. évfordulóját. Ebből az ünnepi alkalomból neves előadók tartottak előadást a MANYE múltjáról, jelenéről és jövőjéről. A koronavírus-járvány miatt a Zoom online platformon megrendezésre kerülő konferencia majdnem 80 fö részvételével zajlott. Az ünnepélyes megnyitót Prószéky Gábor, a MANYE elnöke tartotta.
\end{abstract}

Az első előadást Klaudy Kinga, az ELTE Fordítástudományi Doktori Iskola vezetője, a MANYE alelnöke és korábbi elnöke tartotta. A félórás elöadásban professzor asszony bemutatta a MANYE történetének mérföldköveit, melyet az előadás címe is egyértelmüsített: Az alkalmazott nyelvészek szakmai közösséggé formálódása a 20. század végén és a 21. század elején. A MANYE első 30 éve három nagy korszakra osztható: az első korszak a megalakulásról szólt a rendszerváltástól egészen a kongresszussá alakulásig (1990-1998); a második korszak már a hosszabb konszolidációs időszakot foglalta magába (1999-2015); a harmadik korszak pedig a megújulás jegyében indult és még jelenleg is tart (2016-).

Az első korszak két jelentős személyisége Szépe György professzor és Papp Ferenc akadémikus volt, akik 1990-ben elindítói voltak két egymástól független kezdeményezésnek. Az egyik a TIT Idegen Nyelvi Választmányában, másik a Magyar Tudományos Akadémia Alkalmazott Nyelvészeti Bizottságában indult. Szépe György a magyarországi nyelvoktatókat fogta össze a Magyarországi Nyelvoktatók Egyesületének megalapításával, melynek célja a nyelvoktatók képviselete, a döntéshozókkal való kapcsolattartás, továbbképzések és tanácsadás biztosítása, valamint a Modern Nyelvoktatás címü folyóirat előfizethetővé alakítása volt. Papp Ferenc az alkalmazott nyelvészek számára kívánt évente megrendezett konferenciasorozatot indítani az MTA Alkalmazott Nyelvészeti Bizottság keretein belül, hogy a (szak)nyelvoktatás, nyelvtanárképzés és az alkalmazott nyelvészet számos

Hivatkozás: Malaczkov Sz. 2021. A MANYE 30 éves fennállásának jubileumi konferenciája. (MANYE, online konferencia, 2020. december 4.) Forditástudomány 23. évf. 1. szám. 101-104. DOI: https://doi.org/10.35924/fordtud.23.1.6 
területén (pl. kontrasztív nyelvészet, szociolingvisztika, pszicholingvisztika, számítógépes nyelvészet, fordítás és tolmácsolás) elért legfrissebb kutatási eredmények mindenki számára megismerhetök legyenek. A két kezdeményezés találkozott az első három alkalmazott nyelvészeti konferencián (1991 Nyíregyháza, 1992 Szeged, 1993 Miskolc) és 1994-ben a Magyarországi Nyelvoktatók Egyesületének közgyülésén megszületett az egyesület új neve: Magyar Alkalmazott Nyelvészek és Nyelvoktatók Egyesülete (MANYE). Az évente megrendezett konferenciák a 400 fős résztvevői létszám miatt 1998-tól kongresszussá váltak, és 1998-ban megszületett a MANYE logó is. Az egyesület célja elősegíteni az alkalmazott nyelvészetet, különösképpen az idegen nyelveknek (beleértve a magyarnak mint idegen nyelvnek) magyarországi kutatását, oktatását, elterjesztését.

A második korszakban a MANYE életére az egyesület konszolidált müködése volt jellemzö: továbbra is minden évben volt MANYE kongresszus, és a kongresszusi kötetek a következö kongresszusra mindig megjelentek. A kongresszusi kötetek 2006-tól egységes formát öltöttek, kialakult a MANYE hivatkozási és konferenciaszervezési útmutatója is. Az alkalmazott nyelvészet területén kiemelkedő teljesítményt nyújtó kutatók pedig 1999 óta Brassai-díjban részesülhetnek. Szépe György 17 évig volt a MANYE elnöke, 2008-ban Klaudy Kinga vette át az elnökséget. A MANYE biztosítja az alkalmazott nyelvészek és nyelvtanárok számára a szakmai közösséghez tartozást, a szakmai eseményeken való részvételt, új szakmai kapcsolatok létesítését, az új kutatási eredmények bemutatását, a visszajelzés lehetőségét tapasztalt pályatársaktól és a publikáció lehetőségét is.

A harmadik korszakot, a MANYE jelenét és jövőjét Prószéky Gábor, aki 2013 óta a MANYE elnöke, és Seidl-Péch Olívia a MANYE titkára, a BME oktatója, közös előadásban mutatták be. Prószéky Gábor először az alkalmazott nyelvészeti kutatások helyét és szerepét határozta meg a tudományos kutatások rendszerében. Alkalmazott kutatás csak olyan tudományágnál lehetséges, amelynek kutatása valamilyen gyakorlati tevékenység szempontjából rendkívül fontos. Az alkalmazott nyelvészeti kutatás ezenkívül azt jelenti, hogy az alkalmazott nyelvészet valamely szakterületét kutatjuk, legyen az nyelvoktatás, fordítástudomány, lexikográfia, terminológia, pszicholingvisztika, stb. Az alkalmazott kutatások gyakran interdiszciplináris vagy multidiszciplináris jellegüek. A kutatásokat finanszírozni, a kutatási eredményeket pedig publikálni kell, hasonlóan az alapkutatásokhoz. A kutatási területek folyamatosan változnak, így időröl-időre át kell gondolni, hogy az alkalmazott nyelvészeten belül is milyen irányokat lehet kijelölni.

A kutatási területek mellett a kutatási környezet is változik. Korábban a MANYE biztosította az egyik legjelentősebb szakmai fórumot, amelynek éves konferenciáin a szakma szinte minden jeles képviselője részt vett. Seidl-Péch Olívia szerint azonban a mai szakmai életet a konferenciák és a publikációs lehetőségek túlkínálata jellemzi, a szakmai szerveződések kisebb egységekre töredeztek, és a doktori képzés rendszere is alapvetően megváltozott. A megoldás az lehet, ha egyrészt a MANYE a szakmai életet hatékonyan müködő kisebb szakosztályokba szervezi, és ezek a szakosztályok a kutatási területüknek megfelelő témában kisebb 
konferenciákat szervezhetnek a MANYE keretein belül. Jelenleg három szakosztály müködik (Magyar mint Idegen Nyelvi Szakosztály, Fordítástudományi Szakosztály, Terminológiai Szakosztály), amelyeknek saját továbbképzéseik, konferenciáik és kiadványaik is megjelentek már. Másik megoldási lehetőség a szakmai összefogás és a hatékony kommunikáció biztosítása lehet. Az egyes kutató- és képző intézmények közös konferencianaptár segítségével tervezhetnék meg a konferenciák, továbbképzések és egyéb programok egyenlő eloszlását az adott évben. A hatékony kommunikációt a MANYE új honlapja is segíti. Harmadrészt pedig cél a fiatalok, a doktori programokban részt vevő hallgatók, a jövő kutatóinak megfelelő mentorálása és integrálása a szakmai szervezetbe.

Az alkalmazott nyelvészeti kutatásokat az elméleti nyelvészeti kutatásokkal összekötő előadásában (Az alkalmazott nyelvészet leiró és elméleti nyelvészeti hozadékai) É. Kiss Katalin akadémikus, a PPKE egyetemi tanára hangsúlyozta, hogy az alkalmazott nyelvészet fontos tanulságokkal szolgálhat az elméleti nyelvészet számára. Három szakterületről hozott példákat: a számítógépes nyelvészet, a nyelvmüvelés és a pszicholingvisztika területéröl. Papp Ferenc teremtette meg az 1960-as években a számítógépes nyelvészet, azon belül pedig a számítógépes lexikográfia központját a debreceni egyetemen. A számítógépes adatbázisuk segítségével létrehozott Szóvégmutató szótár (1969) elméleti nyelvészeti hozadéka a magyar főnév morfológiájának első formális leírása (1975) lett. A nyelvmüvelés területén a nyelvi változások felismerése vezethet később elméleti nyelvészeti következtetések levonásához. Nádasdy Ádám észrevette például, hogy a magánhangzóra végződő melléknevek többes jele elött terjed a kötőhangzó (támadóak, kétkedőek). Az elméleti nyelvészeti kutatások ezután kimutatták, hogy kialakulóban van a többes szám melléknevekhez járuló allomorfja. Ugyancsak nyelvmüvelök figyeltek fel a felesleges igekötők használatára (bebiztosít, leredukál). Az elméleti nyelvészek ebböl arra tudtak következtetni, hogy a befejezett, azaz inherens végponttal bíró eseményt kifejező igék már mind igekötősök lettek. A pszicholingvisztika például a gyermeknyelv kutatásában lehet az elméleti nyelvészet segítségére. Pszicholingvisztikai kutatások kimutatták, hogy a 'néhány' szót máshogy értelmezik a gyermekek ('kevés') és a felnőttek ('nem mind'). Az erre épülő elméleti nyelvészeti kutatások bebizonyították, hogy a gyermekek elöször a 'néhány' nem-specifikus ('kevés') jelentését tanulják meg, és még nem érzékenyek a különféle mondatpozíciókban fellépő specifikus ('nem mind') jegyekre. Az alkalmazott nyelvészeti kutatások tehát hozzájárulnak az elméleti kutatásokhoz, ahogy az elméleti nyelvészeti kutatások is hozzájárulnak az alkalmazott kutatásokhoz.

Végül a MANYE kiadványát, a Modern Nyelvoktatást, a folyóirat föszerkesztője, Nádor Orsolya mutatta be. A Modern Nyelvoktatás múltját, jelenét és jövőjét három nagy korszakra osztotta: a MANYE előtti időszakra, a MANYE elmúlt 30 évéhez kötődő időszakra és a jelen átalakulási folyamatára. Az első korszak (19631989) a TIT-hez mint a magyarországi idegennyelv-oktatás fellegvárához köthető. A TIT állami keretek között biztosította a felnőttek idegennyelv-oktatását, és a felhalmozott elméleti és módszertani nyelvpedagógia ismeretek széles körű ter- 
jesztéséhez járult hozzá az önkéntes alapon szerkesztett Modern Nyelvoktatás címü folyóirat. A nyelvpedagógiai témák érintették a kontrasztív nyelvészet és a fordítás szerepét a nyelvoktatásban, az országismeretet, a hibaelemzést, a szókincsminimumot, és többek között az idegen nyelvi mérést is. A nyelvpedagógia mellett az alkalmazott nyelvészet más területei is helyet kaptak a folyóiratban, például a fordítástudomány, a pszicholingvisztika, a lexikográfia és a pragmatika.

1995-ben, a MANYE megalakulásával, új korszak kezdődött a Modern Nyelvoktatás életében. Az újrainduló folyóirat, melynek föszerkesztője Szépe György lett, az alkalmazott nyelvészet minden területéről jelentetett meg írásokat. Foglalkozott a magyar anyanyelvi oktatással, az idegen nyelvek oktatásával, a kétnyelvü oktatással, valamint fordítással, lexikológiával, terminológiával, nyelvpolitikával és szociolingvisztikával is. A folyóirat megjelenése, kiadása és terjesztése profeszszionális lett és 2018-ban bekerült az MTA Nyelv és Irodalomtudományi Osztálya által jegyzett folyóiratai közé.

Jelenleg a folyóirat online megjelentetése a cél. Az Elektronikus Periodika Archívum és Adatbázisban (epa.oszk.hu) már megtalálhatók a Modern Nyelvoktatás cikkei online formában is, az 1995-ben megjelent számoktól folyamatosan. 2021-től a folyóirat már csak online formában jelenik meg, és a MANYE megújult honlapján külön menüpontból elérhető. A folyóirat bekerül az Open Journal System (OJS) rendszerébe, és a cikkek visszamenőleg is DOI azonosítót kapnak. Az online megjelenés növelheti a folyóirat nemzetközi ismertségét és a publikációk széleskörü megismertetését.

A MANYE 30. jubileumi konferenciáján elhangzott előadások írott változata a Modern Nyelvoktatás egyik következő számában lesz olvasható. Az előadások diái viszont már most megtekinthetők a MANYE szintén idén megújult honlapján a következő linken: https://manye.hu/kongresszusok/konferencia-manye-30. 